Sains Malaysiana 50(5)(2021): 1367-1379

http://doi.org/10.17576/jsm-2021-5005-16

\title{
Survival Analysis and Prognostic Factors for Prostate Cancer Patients at Universiti Kebangsaan Malaysia Medical Centre, Kuala Lumpur
}

(Analisis Kemandirian dan Faktor Prognostik bagi Pesakit Kanser Prostat di Pusat Perubatan Universiti Kebangsaan

Malaysia, Kuala Lumpur)

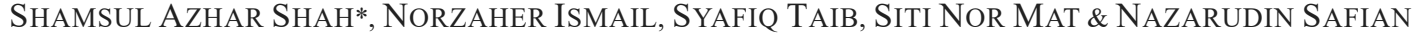

\begin{abstract}
Prostate cancer is the third commonest type of cancer in Malaysian men with the incidence of 1,807 in 2018 compared to 1,186 cases reported in 2014. Prostate cancer is also known to cause disease, economic burden and lead to significant financial implications for the healthcare system. This study aimed to measure the rate of survival and to determine the prognostic factors for prostate cancer patients at Universiti Kebangsaan Malaysia Medical Centre, Kuala Lumpur. This was a retrospective study design involving prostate cancer patients who had been diagnosed and had sought treatment at Universiti Kebangsaan Malaysia Medical Centre from 2008 to 2017. Data were obtained from the patients'medical records based on TRUS biopsy. The study period was from July 2017 to December 2018. Survival probabilities were estimated using Kaplan-Meier, and differences were compared using the log-rank test. The adjusted hazard ratio (HR) for variables was estimated after fitting the Cox proportion hazard model. Patients' death status due to prostate cancer was the endpoint of the survival analysis. A total of 283 patients' data were analysed. Total five-year and ten-year survival rates of prostate cancer patients were 77.8 and $65.5 \%$, respectively, regardless of the stage and treatment. The predictor factors for survival age were $\geq 75$ years (HR $=8.49$, 95\% C.I: 1.16-62.13), Gleason score $\geq 8$ (HR $=2.36$, 95\% C.I: 1.18-4.73) and cancer metastasis complications (HR =5.26, 95\% C.I: 2.88-9.63). Survival rates and prognostic factors of prostate cancer in the study were almost similar to those in nearby countries in the region. Preventive actions such as prostate cancer screening, early detection of cancer and early treatment should be empowered to improve the survival rate of prostate cancer patients in this hospital.
\end{abstract}

Keywords: Prognostic factor; prostate cancer; survival analysis

ABSTRAK

Kanser prostat ialah jenis kanser yang ketiga tertinggi di kalangan lelaki Malaysia dengan kadar insiden 1,807 kes pada tahun 2018 berbanding 1,186 kes pada tahun 2014. Kanser prostat juga diketahui sebagai punca beban penyakit, beban ekonomi dan menyebabkan implikasi kewangan yang signifikan kepada sistem penjagaan kesihatan. Kajian ini bertujuan untuk mengukur kadar kemandirian dan menentukan faktor prognostik untuk pesakit kanser prostat di Pusat Perubatan Universiti Kebangsaan Malaysia, Kuala Lumpur. Reka bentuk kajian adalah retrospektif yang melibatkan pesakit kanser prostat yang telah didiagnos dan mendapatkan rawatan di UKMMC dari 2008 hingga 2017. Data diperoleh daripada rekod perubatan pesakit berdasarkan biopsi kelenjar prostat. Tempoh kajian adalah dari Julai 2017 sehingga Disember 2018. Kadar kemandirian dianggarkan menggunakan Kaplan-Meier dan perbezaannya dibandingkan dengan ujian Log-Rank. Nisbah Hazard untuk pemboleh ubah dianggarkan menggunakan Model Hazad Berkadaran Cox. Status kematian pesakit akibat kanser prostat adalah titik akhir analisis kemandirian hidup. Sebanyak 283 data pesakit dianalisis. Jumlah pesakit kanser prostat sepanjang 5 tahun dan 10 tahun adalah 77.8 dan 65.5\% tanpa mengira tahap dan jenis rawatan. Faktor prognostik untuk kemandirian hidup adalah umur $\geq 75$ tahun $(\mathrm{NH}=8.49,95 \%$ SK 1.16-62.13), skor Gleason $\geq 8(\mathrm{NH}=2.3695 \%$ SK 1.18-4.73) dan komplikasi metastasis kanser $(\mathrm{NH}=5.2695 \%$ SK 2.88 -9.63). Kadar kemandirian dan faktor prognostik kanser prostat dalam kajian ini hampir sama dengan negara berdekatan di rantau ini. Tindakan pencegahan seperti pemeriksaan kanser prostat, pengesanan awal kanser dan rawatan awal harus diberi fokus untuk meningkatkan kadar kemandirian hidup pesakit kanser prostat di hospital ini.

Kata kunci: Analisis kemandirian; faktor prognostik; kanser prostat 


\section{INTRODUCTION}

According to the World Health Organization (WHO), prostate cancer was the fourth commonest cancer after lung cancer, colorectal cancer, and nasopharyngeal cancer for Malaysian men with 1,186 new cases (WHO 2014). The incidence of prostate cancer was thereafter reported to have increased to 1,807 , accounting for $8.8 \%$ of the total cancer of the Malaysian men in 2018 and thus making prostate cancer the third commonest cancer of males in Malaysia after lung cancer and colorectal cancer (Bray et al. 2018). In Malaysia, Lim (2002) discussed that the annual death rate per 100,000 people from prostate cancer increased by $93.7 \%$ over the last 25 years since 1990 , with an average increase of $4.1 \%$ per year. In 2030, the incidence of prostate cancer is expected to increase to 1.7 million new cases and 499,000 deaths worldwide. At that time, prostate cancer will be known as the commonest type of cancer in men as it will contribute to $15 \%$ of all new cancer cases in males. It is also predicted that $70 \%$ of all new cases of prostate cancer will occur in developed countries (Ferlay et al. 2012; He \& Chen 2012; Ramsey et al. 2007).

Ezat et al. (2013) reported that the cost of treatment for late-stage prostate cancer patients with bone metastasis complications accounted for about $11.12 \%$ of the total burden of disease involving bone metastases as reported by the Ministry of Health Malaysia. A study by Satoh et al. (2018) in Japan reported that prostate cancer patients with a skeletal event led to a significant increase in costs and healthcare resource utilisation and increased economic burden on patients. The study concluded that bone metastasis complications for prostate cancer have had significant financial implications for the healthcare system 's provision of patient treatment facilities including medication, radiotherapy, a laboratory, imaging, surgery, and use of analgesics.

According to the Malaysia National Cancer Registry Report, almost $50 \%$ of cancer patients are not registered and diagnosed at the late stage, and this leads to increased treatment costs. Besides that, this study was also aimed at assisting the public and staff to understand the factors that affect prostate cancer patient's survival. This study aimed to measure the survival rate of prostate cancer patients diagnosed and treated at Universiti Kebangsaan Malaysia Medical Centre (UKMMC) Kuala Lumpur, and to investigate the prognostic factors for prostate cancer survival.

\section{MATERIALS AND METHODS}

The study design was a retrospective cohort with approval of the research ethical committee (Research
Ethical Approval No. 2019-249). The sample of the study was a record of patients' who had been diagnosed with prostate cancer and had sought treatment at the Surgery and Oncology Department of HCTM from 2008 to 2017. Patient's data were retrieved from the medical record based on the TRUS biopsy list. Survival status, date, and cause of death were obtained from the National Registry Department, Malaysia. Patients who were diagnosed with other primary cancer than prostate cancer, had an incomplete diagnosis, were non-Malaysian and died due to non-prostate cancer were excluded during the analysis. Clinical data (prostate-specific antigen (PSA) level, Gleason score, and stage), demographic data (age and race) and treatment data were entered on a standard data collection sheet. The PSA test is a blood test used primarily to screen for prostate cancer. The test measures the amount of a PSA in the blood. PSA is a protein produced by both cancerous and non-cancerous tissue in the prostate, a small gland that sits below the bladder in men. The histopathology and imaging investigation results were retrieved from a computerised-system as reported by pathologists and radiologists. The staging of the disease was based on the American Joint Committee on Cancer 2002 (Hittelman et al. 2004).

\section{RESPONDENT SAMPLING}

All patients' data or records with prostate cancer diagnosed from 2008 to 2017 were selected, involving patients who had been diagnosed and had received treatment at the Urology Clinic, had received radiotherapy and chemotherapy at the Oncology Department admitted to the Urology ward for treatment or observation purposes. The measured event was the endpoint event status (date of death) issued by the National Registration Department, Malaysia. Other patients who were still undergoing further treatment or had defaulted were categorised as censored cases. The time to death of each patient is calculated from the date of diagnosis of the patient to the date of death, and the end date of the study date is fixed at 31 st December 2018. The respondent inclusion criteria were Malaysian citizenship, registration at the HCTM, a complete diagnosis (Stage 1, Stage 2, Stage 3, Stage 4) and consent to participate in the study.

\section{DATA ANALYSIS}

The data were analysed using the Statistical Package for Social Sciences version 21. The probabilities of five-year and ten-year survival were estimated using the KaplanMeier method, and differences in survival effects were compared using the log-rank test. The mean survival 
rate, calculated as the number of uncensored data, was less than 50\%. The Cox proportion hazard model was used to measure the adjusted hazard ratio (HR) for the prognostic factors for prostate cancer, and the associated $95 \%$ confidence intervals were obtained. The survival time of a patient is referred to as the number of months from the day the patient was diagnosed until he dies or until the end of the study period ( $31^{\text {st }}$ December 2018). A p-value $<$ 0.05 was identified as statistically significant.

\section{RESULTS}

A total of 311 patients were diagnosed with prostate cancer from 2008 to 2017 by TRUS biopsy in this hospital. After excluding the numbers of the patient according to the research criteria (Figure 1), a total of 283 patient's data were analysed. Of these, $52.3 \%$ were patients aged 75 and above, $36.0 \%$ were 65 to 74 years old, and the rest $11.7 \%$ were less than 65 years old. In terms of race category, the Chinese showed the highest percentage with 57.6\% (163 patients), followed by Malays at 36.7\% (104 patients) and Indians at $5.7 \%$ (16 patients).

For the stage of cancer distribution, a total of 201 patients $(71.0 \%)$ were diagnosed as with early-stage cancer (Stages 1 and 2), and 82 patients (29.0\%) were diagnosed with an advanced-stage cancer (Stages 3 and 4). Also, 113 patients $(39.9 \%)$ in the study had cancer metastasis complications, and 79 patients $(27.9 \%)$ had cancer spread to the lymph nodes. The type of treatment showed that 53 patients $(18.7 \%)$ received active surveillance treatment, 105 patients $(37.1 \%)$ received hormonal therapy treatment, 27 patients $(9.5 \%)$ had surgical intervention and 98 patients (34.6\%) received combination treatment. The result also indicated that only $64(22.6 \%)$ of the prostate cancer patients died of prostate cancer (Table 1).

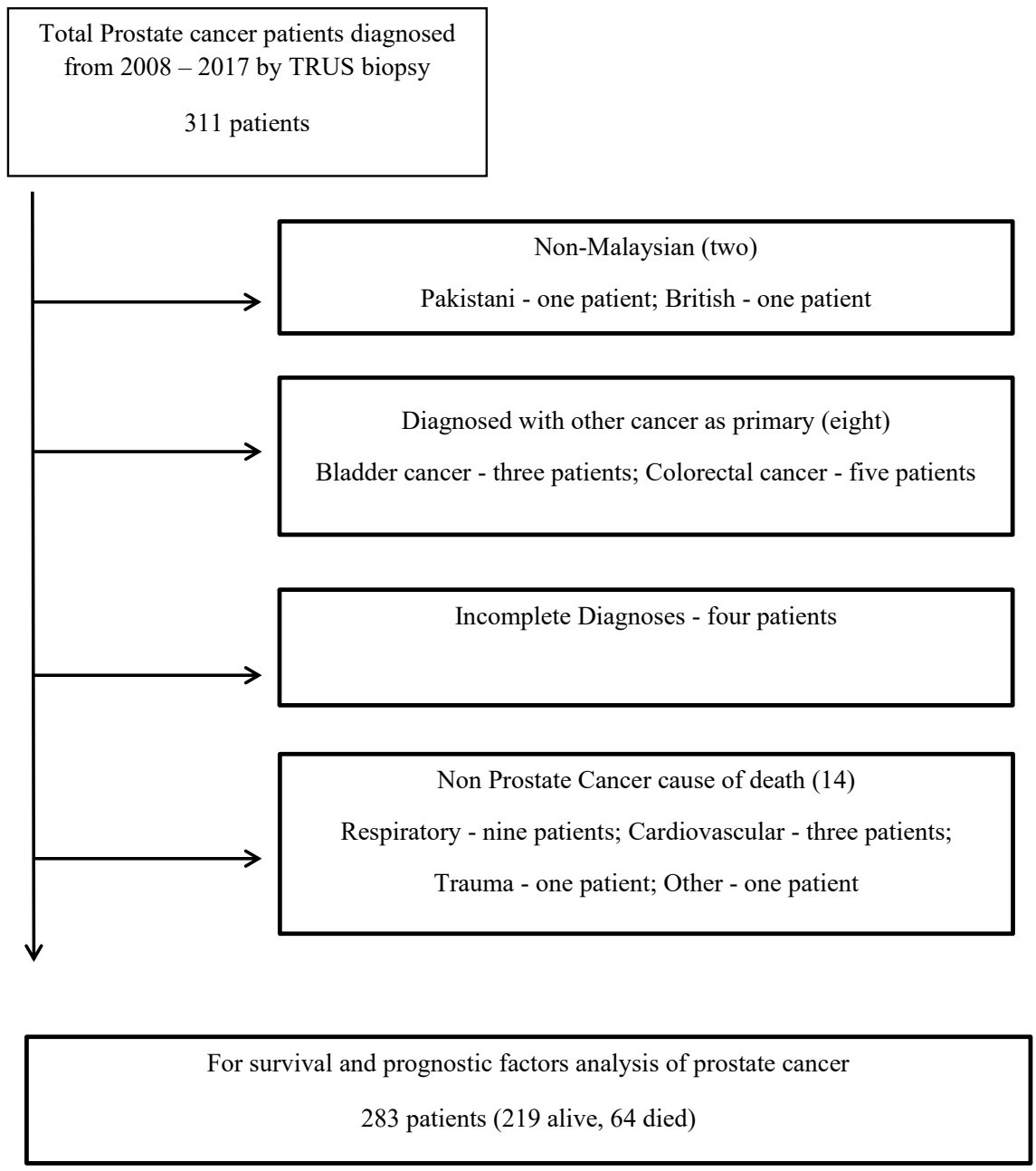

FIGURE 1. Selection of prostate cancer patients in the study 
TABLE 1. Demographic characteristics of prostate cancer patients, 2008-2017 (N=283)

\begin{tabular}{|c|c|c|}
\hline Demographic characteristics & $\mathrm{n}$ & $\%$ \\
\hline \multicolumn{3}{|l|}{ Age } \\
\hline$<65$ & 33 & 11.7 \\
\hline$\geq 65-74$ & 102 & 36.0 \\
\hline$\geq 75$ & 148 & 52.3 \\
\hline \multicolumn{3}{|l|}{ Race } \\
\hline Malay & 104 & 36.7 \\
\hline Chinese & 163 & 57.6 \\
\hline Indian & 16 & 5.7 \\
\hline \multicolumn{3}{|l|}{ Cancer Stage } \\
\hline Stage 1 & 38 & 13.4 \\
\hline Stage 2 & 162 & 57.3 \\
\hline Stage 3 & 72 & 25.4 \\
\hline Stage 4 & 11 & 3.9 \\
\hline \multicolumn{3}{|l|}{ Gleason score } \\
\hline$\leq 6$ & 100 & 35.3 \\
\hline 7 & 75 & 26.5 \\
\hline$\geq 8$ & 108 & 38.2 \\
\hline \multicolumn{3}{|l|}{ Prostate specific antigen $(\mathrm{ng} / \mathrm{mL})$} \\
\hline$<10.00$ & 79 & 27.9 \\
\hline$\geq 10.00-19.99$ & 65 & 23.0 \\
\hline$\geq 20.00$ & 139 & 49.1 \\
\hline \multicolumn{3}{|l|}{ Lymph nodes } \\
\hline Yes & 79 & 27.9 \\
\hline No & 204 & 72.1 \\
\hline \multicolumn{3}{|l|}{ Cancer metastasis } \\
\hline Yes & 113 & 39.9 \\
\hline No & 170 & 60.1 \\
\hline \multicolumn{3}{|l|}{ Treatment } \\
\hline Active surveillance & 53 & 18.7 \\
\hline Hormonal therapy & 105 & 37.1 \\
\hline Surgical & 27 & 9.6 \\
\hline Combination therapy & 98 & 34.6 \\
\hline \multicolumn{3}{|l|}{ Status } \\
\hline Alive & 219 & 77.4 \\
\hline Death & 64 & 22.6 \\
\hline
\end{tabular}




\section{KAPLAN MEIER AND LOG-RANK TEST}

The study demontrated that the overall five-year and tenyear survival rates were $77.8 \%$ and $65.5 \%$, respectively, regardless of stage and type of treatment, with a survival mean of 111.3 months (95\% C.I: 103.7-118.9). The survival mean for early prostate cancer patients was 114.8 months (95\% C.I: $106.0-123.5)$ whereas that of patients in advanced stages was 90.8 months (95\% C.I 79.0-102.6). The five-year and ten-year survival rates recorded 81.2 and $68.9 \%$ for early-stage cancer and 71.7 and $55.9 \%$ for advanced-stage cancer for the same period of survival.
Kaplan-Meier (Figures 2 - 7) and Log-Rank tests also found that factors such as age $\left(\chi^{2}=27.61, p<0.001\right)$, Gleason score $\left(\chi^{2}=24.05, p<0.001\right)$, types of treatment $\left(\chi^{2}=21.88, p<0.001\right)$, cancer metastasis $\left(\chi^{2}=62.56, p<\right.$ $0.001)$, lymph nodes $\left(\chi^{2}=10.03, p=0.002\right)$ and PSA level $\left(\chi^{2}=22.01, p<0.001\right)$ showed statistical significance in survival rate difference, whereas factors such as stage of cancer $\left(\chi^{2}=2.36, p=0.124\right)$ and race $\left(\chi^{2}=4.76, p=\right.$ $0.093)$ showed no significant difference in the survival rate (Table 2).

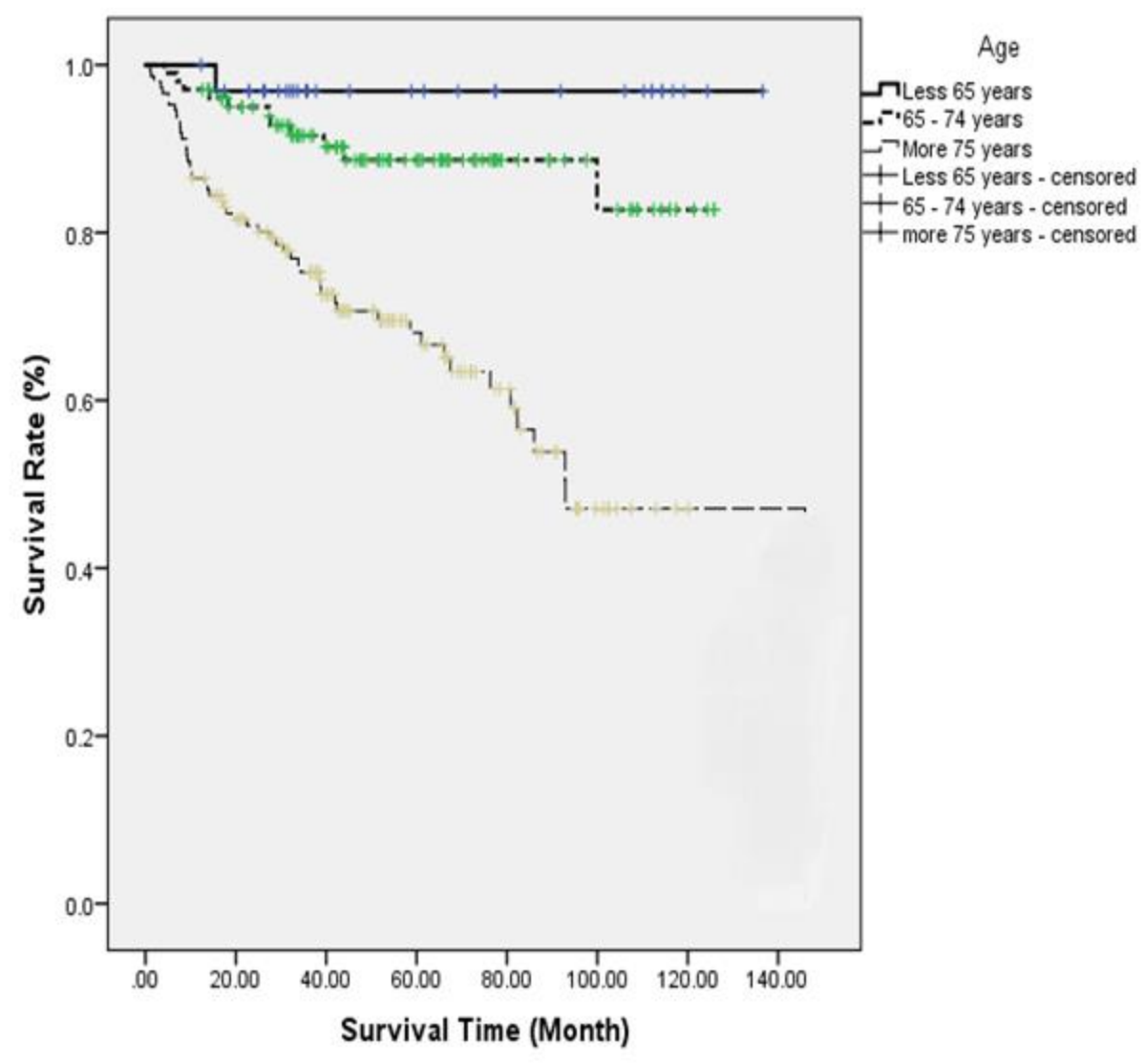

FIGURE 2. Prostate cancer survival curve based on age 


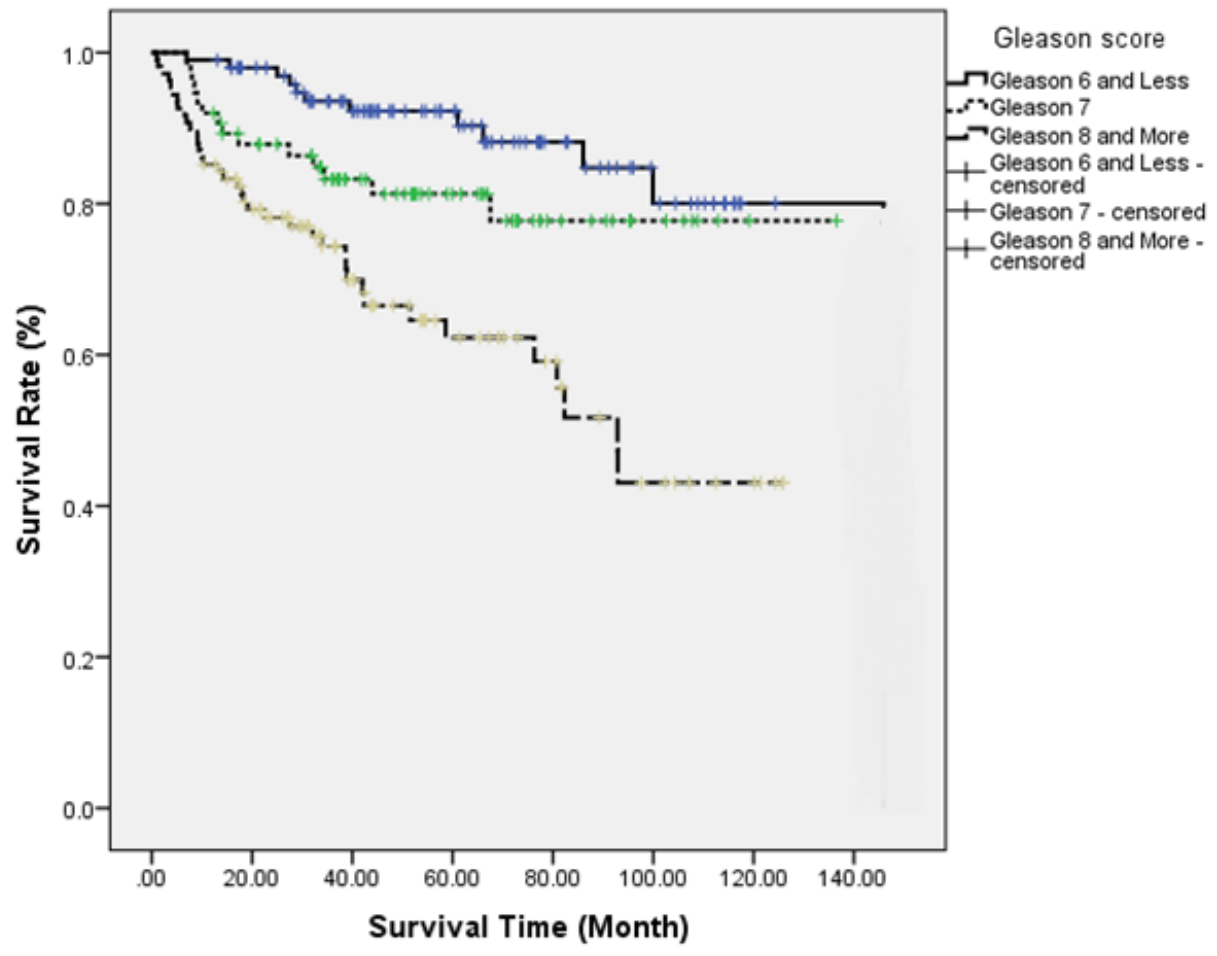

FIGURE 3. Prostate cancer survival curve based on Gleason score

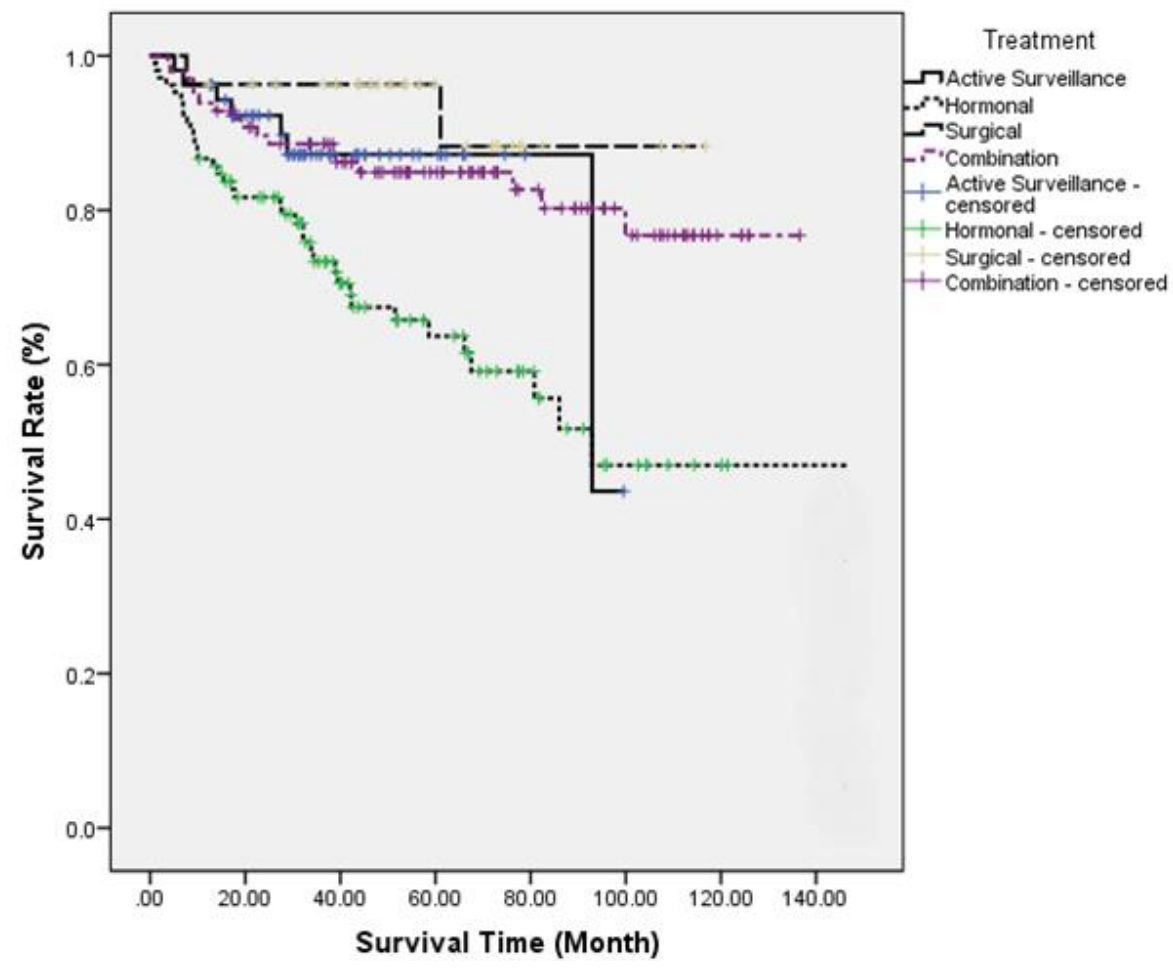

FIGURE 4. Prostate cancer survival curve based on type of treatment 


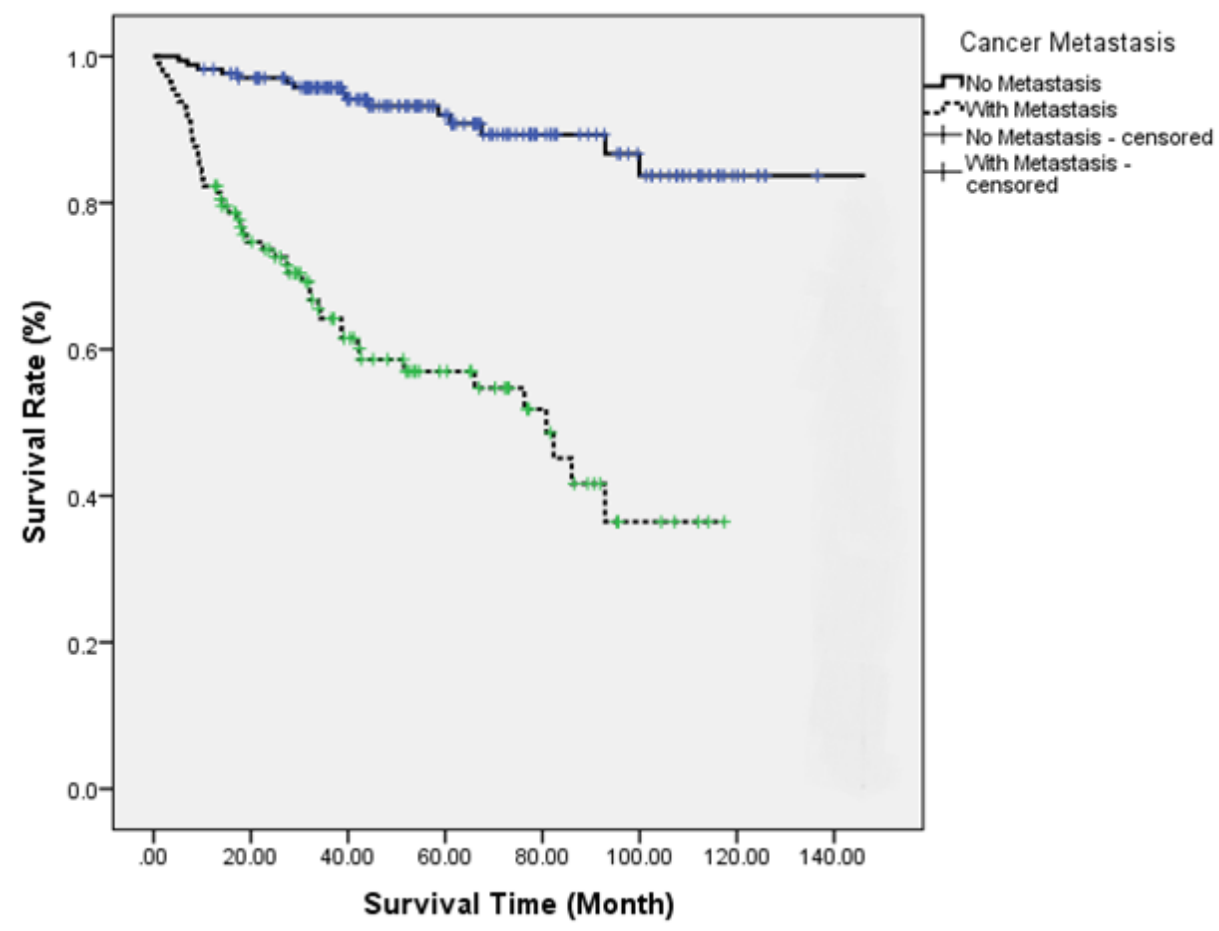

FIGURE 5. Prostate cancer survival curve based on cancer metastasis

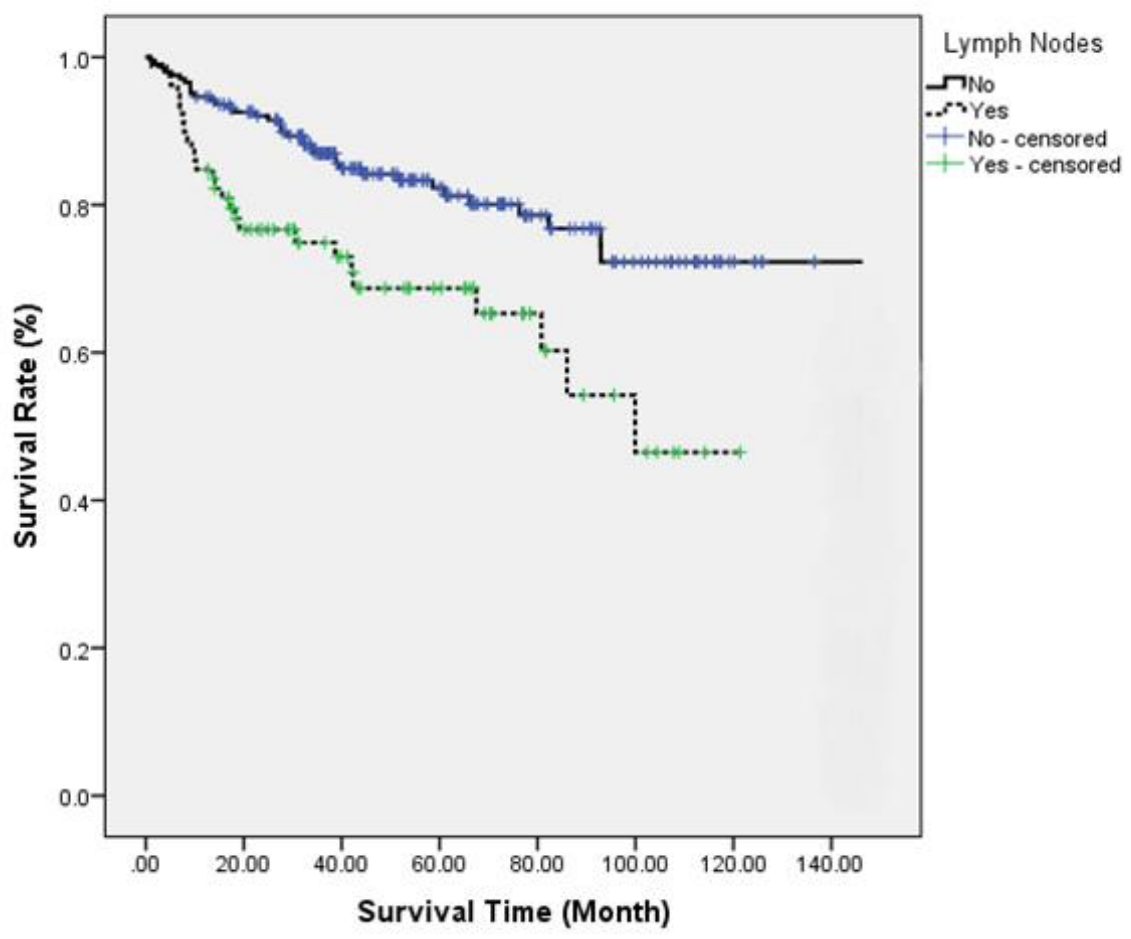

FIGURE 6. Prostate cancer survival curve based on lymph nodes 


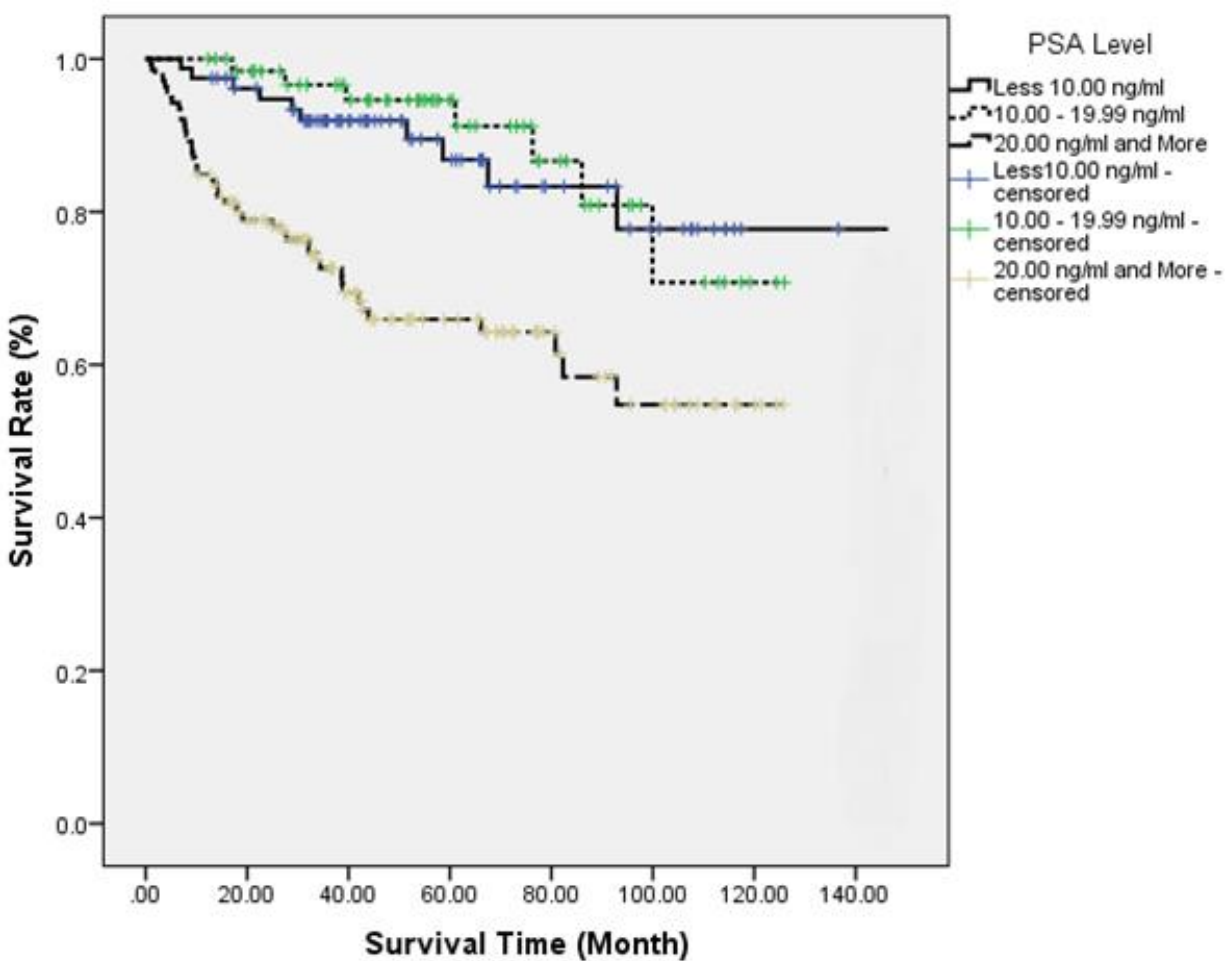

FIGURE 7. Prostate cancer survival curve based on prostate specific antigen (PSA)

\section{PROGNOSTIC FACTOR}

The prognostic factor for prostate cancer patients was analysed using the Cox proportional hazard regression model (Forward LR) test method. The analysis found that three factors contributed significantly to the event of the death due to prostate cancer. Those were patients age $\geq 75$ years $(\mathrm{HR}=8.49,95 \%$ C.I: $1.16-62.13)$, Gleason score $\geq 8$ $(\mathrm{HR}=2.36,95 \%$ C.I: $1.18-4.73)$ and cancer metastasis $(\mathrm{HR}=5.26,95 \%$ C.I: 2.88 - 9.63). These three factors were then tested for the interaction and multi-collinearity for the reliability of the prognostic factors for prostate cancer before final model fitness was tested (Table 3).

TABLE 2. Univariate analysis of prostate cancer patient using Kaplan-Meier and Log-Rank Test

\begin{tabular}{|c|c|c|c|c|c|c|c|c|}
\hline \multirow[b]{2}{*}{ Factors } & \multicolumn{3}{|c|}{ Number of patient } & \multicolumn{3}{|c|}{ Survival rate } & \multirow[b]{2}{*}{$\chi^{2}(\mathrm{~d} . \mathrm{f})$} & \multirow[b]{2}{*}{ p-value } \\
\hline & $\begin{array}{l}\text { Alive } \\
\mathrm{n}(\%)\end{array}$ & $\begin{array}{l}\text { Dead } \\
\text { n }(\%)\end{array}$ & $\begin{array}{c}5 \text { year } \\
(\%)\end{array}$ & $\begin{array}{c}10 \text { year } \\
(\%)\end{array}$ & $\begin{array}{c}\text { Mean (S.D) } \\
\text { (Month) }\end{array}$ & $95 \%$ C.I & & \\
\hline \multicolumn{9}{|l|}{ Age } \\
\hline$<65$ & $32(97.0)$ & $1(3.0)$ & 96.9 & 96.9 & $132.8(3.7)$ & $125.5,140.1$ & $27.61(2)$ & $<0.001$ \\
\hline$\geq 65-74$ & $91(89.2)$ & $11(10.8)$ & 88.6 & 82.7 & $112.8(3.7)$ & $105.6,120.1$ & & \\
\hline$\geq 75$ & $96(64.9)$ & $52(35.1)$ & 68.1 & 47.1 & $92.7(5.8)$ & $81.2,104.2$ & & \\
\hline \multicolumn{9}{|l|}{ Race } \\
\hline Malay & $75(72.1)$ & $29(27.9)$ & 69.9 & 60.2 & $90.0(5.5)$ & $79.2,100.8$ & $4.76(2)$ & 0.093 \\
\hline Chinese & $132(81.0)$ & $31(19.0)$ & 83.2 & 68.5 & $116.8(4.8)$ & $107.3,126.3$ & & \\
\hline Indian & $12(75.0)$ & $4(25.0)$ & 79.8 & 69.5 & $82.3(9.5)$ & $63.7,100.9$ & & \\
\hline
\end{tabular}

Cancer stage 


\begin{tabular}{|c|c|c|c|c|c|c|c|c|}
\hline Early stage & $160(79.6)$ & $41(20.4)$ & 81.2 & 68.9 & $114.8(4.5)$ & $106.0,123.5$ & $2.36(1)$ & 0.124 \\
\hline $\begin{array}{l}\text { Advanced } \\
\text { stage }\end{array}$ & $59(72.0)$ & $23(28.0)$ & 71.7 & 55.9 & $90.8(6.0)$ & $79.0,102.6$ & & \\
\hline \multicolumn{9}{|l|}{$\begin{array}{l}\text { Gleason } \\
\text { Score }\end{array}$} \\
\hline$\leq 6$ & $88(88.0)$ & $12(12.0)$ & 81.2 & 68.9 & $129.1(5.0)$ & $119.3,138.9$ & $24.05(2)$ & $<0.001$ \\
\hline 7 & $61(81.3)$ & $14(18.7)$ & 81.3 & 77.8 & $112.2(5.9)$ & $100.6,123.7$ & & \\
\hline$\geq 8$ & $70(64.8)$ & $38(35.2)$ & 62.3 & 43.1 & $79.5(5.7)$ & $68.4,90.6$ & & \\
\hline \multicolumn{9}{|c|}{ PSA Level (ng/mL) } \\
\hline$<10$ & $68(86.1)$ & $11(13.9)$ & 86.8 & 77.8 & $125.4(6.4)$ & $112.9,137.9$ & $22.01(2)$ & $<0.001$ \\
\hline$\geq 10-19$ & $58(89.2)$ & $7(10.8)$ & 91.2 & 70.8 & $111.3(4.9)$ & $101.6,121.0$ & & \\
\hline$\geq 20$ & $93(66.9)$ & $46(23.1)$ & 64.3 & 54.8 & $84.7(4.8)$ & $75.2,94.2$ & & \\
\hline \multicolumn{9}{|l|}{ Lymph nodes } \\
\hline Yes & $53(67.1)$ & $26(32.9)$ & 68.7 & 46.5 & $81.2(6.2)$ & $69.1,93.3$ & $10.03(1)$ & 0.002 \\
\hline No & $166(81.4)$ & $38(18.6)$ & 82.3 & 72.3 & $118.2(4.2)$ & $109.9,126.4$ & & \\
\hline \multicolumn{9}{|l|}{ Metastasis } \\
\hline Yes & $65(57.5)$ & $48(42.5)$ & 57.0 & 36.4 & $68.4(4.9)$ & $58.6,78.2$ & $62.56(1)$ & $<0.001$ \\
\hline No & 154 (90.6) & $16(9.4)$ & 92.0 & 83.7 & $131.8(3.6)$ & $124.6,138.9$ & & \\
\hline \multicolumn{9}{|l|}{ Treatment } \\
\hline $\begin{array}{l}\text { Active } \\
\text { Surveillance }\end{array}$ & $46(86.8)$ & $7(13.2)$ & 87.2 & 43.6 & $86.2(4.4)$ & $77.6,94.7$ & $21.88(3)$ & $<0.001$ \\
\hline Hormonal & $67(63.8)$ & $38(36.2)$ & 63.7 & 47.0 & $90.9(7.1)$ & $77.1,104.8$ & & \\
\hline Surgical & $25(92.6)$ & $2(7.4)$ & 88.3 & 88.3 & $108.2(5.7)$ & $96.9,119.4$ & & \\
\hline Combination & $81(82.7)$ & $17(17.3)$ & 84.9 & 76.8 & $115.0(4.7)$ & $105.8,124.3$ & & \\
\hline
\end{tabular}

Note : Survival Analysis using Kaplan-Meier , $\chi^{2,}$ Log-Rank test

TABLE 3. Multivariate analysis of prognostic factors influencing survival of prostate cancer patients

\begin{tabular}{|c|c|c|c|c|c|c|}
\hline Factor & $\beta$ & S.E & ${ }^{\mathrm{a} C}$ Crude HR (95\% C.I) & ${ }^{\mathrm{b}}$ Adjusted HR (95\% C.I) & Wald (d.f) & $p$-value \\
\hline \multicolumn{7}{|l|}{ Age } \\
\hline$<65$ & & & & & $15.98(2)$ & $<0.001$ \\
\hline$\geq 65-74$ & 0.95 & 1.05 & $3.90(0.50,30.26)$ & $2.59(0.33,20.17)$ & $0.82(1)$ & 0.365 \\
\hline$\geq 75$ & 2.14 & 1.02 & $14.38(1.98,104.39)$ & $8.49(1.16,62.13)$ & $4.43(1)$ & 0.035 \\
\hline \multicolumn{7}{|c|}{ Gleason Score } \\
\hline$\leq 6$ & & & & & $7.12(2)$ & 0.280 \\
\hline 7 & 0.32 & 0.41 & $1.96(0.89,4.33)$ & $1.38(0.62,3.07)$ & $0.62(1)$ & 0.430 \\
\hline$\geq 8$ & 0.32 & 0.35 & $4.39(2.24,8.61)$ & $2.36(1.18,4.73)$ & $5.90(1)$ & 0.015 \\
\hline Metastasis & 1.66 & 0.31 & $6.97(3.89,12.51)$ & $5.26(2.88,9.63)$ & $29.00(1)$ & $<0.001$ \\
\hline
\end{tabular}

${ }^{a}$ Simple Cox Regression ${ }^{b}$ Multiple Cox Proportional Hazard Regression

The model reasonably fits well. Proportional hazard assumption is met. There are no interaction and multicollinearity problem 


\section{DISCUSSION}

This study found that prognostic factors of the prostate cancer patients in UKMMC were age, Gleason score and presence of cancer metastases. The study found that most of the patients who came for the treatment were older than 75 years $(52.3 \%)$, with the majority of them being Chinese $(57.6 \%)$. In this study, age was one of the prognostic factors for prostate cancer patients. Prostate cancer patients older than 75 years had more than eight times the mortality risk of cancer compared to patients in other age categories. However, the age factor alone cannot be explained as a determinant because the rate of survival is often influenced by other factors such as comorbid diseases and cancer-related factors. This is similar to studies by Bechis et al. (2011) and Subahir et al. (2009), who reported that age varied to the rate of survival for prostate cancer as most patients over 75 years old were most likely to be less aggressively treated because of their decreased body physiology.

Also, studies by Bechis et al. (2011) and Sun et al. (2009) reported that age factors also lead to situations where cancer stage and Gleason scores will also be affected. Studies demonstrated that prostate cancer patients diagnosed at age over 70 years have a higher risk of developing prostate cancer at an advanced-stage with a risk of $52.1 \%$ compared with $33.0 \%$ risk for patients under 60 years of age. The same finding was seen in the survival analysis study among 113 patients in Iran by Zahir et al. (2014), which reported that patient age at the time of diagnosis was a significant predictor of prostate cancer survival $(\mathrm{p}<0.05)$.

This study also found that the stage of cancer did not significantly affect the survival rate of cancer patients. In the early-stage of cancer, the challenge of treatment is to maintain the level of survival without aggressive treatment. Two studies conducted among early-stage prostate cancer patients for over 20 years before the introduction of widely used PSA. The first study involved 223 patients who did not receive early treatment and were given anti-androgen hormone treatment if there was aggressive cancer growth. The study found that earlystage prostate cancer was in very slow progress in the first 10 to 15 years. Further monitoring for over 15 to 20 years found that the cumulative growth rate of cancer had decreased (Johansson et al. 2004).

The second study of 24-years of observation involving 767 early-stage prostate cancer patients without metastasis found that there was little risk of death due to metastasis after 20 years for non-aggressive local cancer patients. The study also found that only $29 \%$ of patients died of prostate cancer (Johannsson et al. 2004). A study by Winter et al. (2016) reported that the survival rate for five years after diagnosis varies by country. They noted that studies in Germany found that the five-year survival rate was $96.5 \%$ for the early-stage prostate cancer patients and $27.5 \%$ for the advanced-stage. Another study in Switzerland found that five-year survival rates were $96.1 \%$ for early-stage cancer and $88.9 \%$ for advancedstage cancer (Winter et al. 2016). By contrast, a study by Braga et al. (2017) in Brazil showed death risk rates for advanced-stage cancer patients were tripled (HR $=3.49$ 95\% C.I: $2.91-4.18$ ) when compared to Stage 1 cancer patients, and patients in Stage 3 were having twice risk of death $(\mathrm{HR}=1.6695 \%$ C.I: $1.55-1.79)$ compared to Stage 1 patients.

The results of this study also suggested that other prognostic factor for prostate cancer patients were Gleason's score. The study by Egevad et al. (2002) reported that Gleason's score was important in prediction of the survival rate of patients, with average survival rates for patients with a Gleason score of seven being around 9 to 13 years. Another study by Wright et al. (2009) on 753 prostate cancer patients found that there was a difference in survival rates for patients with different Gleason scores. His study found that the ten-year survival rate was $98.4 \%$ for patients with Gleason score $\leq 6: 76.5 \%$, Gleason score $=7$ and $69.9 \%$ Gleason score $\geq 8$. In a univariate analysis, the study found that the spread of cancer to the lymph nodes had a significant difference in survival rate but was not a prognostic factor to the period of death of prostate cancer patients. To date, there is no special study to show the effects of cancer spread on lymph nodes on the survival of prostate cancer patients. However, one analysis of 61 patients with lymph node involvement by Davidson et al. (1995) against patients without active treatment showed a median survival rate of only 18 months.

By contrast, a study by Zagars et al. (1994) reported a 43-month survival rate in 179 patients with lymph nodes who received anti-androgen hormone therapy. He also stated that the five-year survival rate was $85 \%$ but significantly decreased to $57 \%$ for the eight-year survival rate. A study by Robinson (2008) on the survival of patients with cancer metastases and lymph nodes found that the median survival rate was 8 years, and $31 \%$ of patients were still alive after 13 years of further treatment. The study also reported that $28 \%$ of the mortality rate during the five years after the diagnosis was due to prostate cancer. That study was unable to prove any association between other clinical factors of the mortality of cancer patients. Robinson (2008) also concluded that if a cancer patient had 
lymph node presence, it would overcome other factors on the patient's prognostic condition.

This study found that cancer metastatic complications contribute significantly to the survival rate of prostate cancer patients and reported a significant prognostic factor to cancer deaths at five times higher compared to patients without cancer metastasis $(\mathrm{HR}=5.26)$. This study demonstrated that the five-year survival rate for patients with metastasis was $57 \%$, slightly different from the study conducted by Ryan (2007), which reported 61\% of the five-year survival rate. The study by Mayo Clinic (1925) had reported that the survival rate of cancer patients involving bone metastases for nine months was $66 \%$ (Bumpus 1926). While Nesbit (1946) reported that the average survival of prostate cancer patients with bone metastases was between 1 and 176 months, with the longest surviving patient having survived for 15 years. He also pointed out that for patients with cancer metastases during diagnosis, the opportunity to cure was impossible.

Meanwhile, some other studies have reported that most prostate cancer patients with cancer metastases who received anti-androgen hormone therapy can reduce cancer symptoms and reduce PSA but have a median survival rate of approximately two to three years (Collette et al. 2003; Denis et al. 1998; Glass et al. 2003; Grönberg et al. 1997). A study by Hong et al. (2010) in a university hospital in Malaysia on a seven-year follow-up reported a median survival rate for patients with metastasis of 32.6 months, whereas Phanphaisarn et al. (2016) reported a survival mean of 38.1 months for patients with metastasis in Thailand with a one-year survival rate of $78.8 \%$.

This study demonstrated that there was a significant association between the type of treatment and survival rate of prostate cancer but not in prognostic factors for prostate cancer patients. Although the type of treatment can affect a patient's condition after diagnosis, there was no evidence that the type of treatment is a major factor towards a patient's survival. The study conducted by Bill-Axelson et al. (2011) found no significant advantage over patients receiving radical surgery compared to active surveillance treatment. It was supported by a subsequent study by Wilt et al. (2012) that reported similar results.

Before the use of PSA in 1990, active surveillance and wait-and-watch were commonly practiced. The treatment survival rate was expected to be less than ten years of age, but it gave benefits to patients who have other comorbid diseases. Hence, this type of treatment was an option for patients with a shorter life expectancy such as patients aged over 75 or 80 years with a less aggressive cancer stage (Chodak et al. 1994).
The study by Sandblom et al. (2000) reported that active surveillance treatment had a survival rate of up to $79.7 \%$ for ten years. For the surgical intervention treatment, the study by Wilt (2012) on 731 patients who had undergone a radical prostatectomy surgery found no statistically significant results compared to patients who had received active surveillance treatment, as both treatment-type groups reported $47 \%$ (surgical intervention) and $49.9 \%$ (active survival) for ten-year survival ( $p$-value $=0.220)$.

For the comparison of radiotherapy and prostatectomy, the study by Kishan et al. (2017) on 487 prostate cancer patients with Gleason scores nine and ten found that the survival rate of both types of treatment did not lead to significant differences. Contrarily, the study by Fossa et al. (2016) found that prostate cancer patients who had the combination of radiotherapy and hormone treatment reported a $17 \%$ lower mortality rate compared to patients who had received hormonal therapy, with a $34 \%$ mortality rate. However, the radiotherapy treatment and radical prostatectomy often had side effects such as incontinence and impotence. A meta-analysis study by Wallis et. al (2016) found that radiotherapy treatment may induce other cancer development such as bladder cancer $(\mathrm{HR}=1.7)$ and colorectal cancer $(\mathrm{HR}=1.8)$.

There were a few limitations in this study. Since this is a study using a retrospective cohort method for study design, it has many missing data. The condition of any incomplete data of the variable causes it to be dropped from the analysis. Besides, this study was conducted at a single treatment centre. Hence, the result of this analysis resembles a single treatment centre and not Malaysian prostate cancer patients.

\section{CONCLUSION}

In conclusion, the prognostic factors for prostate cancer survival were age more than 75 years, Gleason scores more than eight and cancer metastasis. Hence preventive actions such as prostate cancer screening, early detection and early treatment should be taken to improve the survival rate of the prostate cancer patients in UKMMC. Hopefully, the results of this study will be approximately in understanding and managing prostate cancer patients and in planning more effective steps to improve the level of survival and quality of life of prostate cancer patients in the future.

\section{ACKNOWLEDGEMENTS}

We would like to acknowledge the Surgical Department, 
Oncology Department, Medical Record Department of HCTM and National Registry Department, Malaysia for assisting in this study.

\section{REFERENCES}

Bechis, S.K., Carroll, P.R. \& Cooperberg, M.R. 2011. Impact of age at diagnosis on prostate cancer treatment and survival. Journal of Clinical Oncology 29(2): 235-241.

Bill-Axelson, A., Holmberg, L., Ruutu, M., Garmo, H., Stark, J.R., Busch, C., Nordling, S., Häggman, M., Andersson, S.O., Bratell, S. \& Spångberg, A. 2011. Radical prostatectomy versus watchful waiting in early prostate cancer. New England Journal of Medicine 364(18): 1708-1717.

Braga, S.F.M., Souza, M.C.D., Oliveira, R.R.D., Andrade, E.I.G., Acurcio, F.D.A. \& Cherchiglia, M.L. 2017. Patient survival and risk of death after prostate cancer treatment in the Brazilian Unified Health System. Revista de Saude Publica 51: 46.

Bray, F., Ferlay, J., Soerjomataram, I., Siegel, R.L., Torre, L.A. \& Ahmedin Jemal. 2018. Global cancer statistics 2018: GLOBOCAN estimates of incidence and mortality worldwide for 36 cancers in 185 countries. CA Cancer J. Clin. 68(6): 394-424.

Bumpus, H.C. 1926. Carcinoma of the prostate: A clinical study of one thousand cases. Surgery, Gynecology and Obstetrics 43: 150-155.

Chodak, G.W., Thisted, R.A., Gerber, G.S., Johansson, J.E., Adolfsson, J., Jones, G.W., Chisholm, G.D., Moskovitz, B., Livne, P.M. \& Warner, J. 1994. Results of conservative management of clinically localized prostate cancer. New England Journal of Medicine 330(4): 242-248.

Collette, L., de Reijke, T.M., Schröder, F.H. \& EORTC GenitoUrinary Group. 2003. Prostate specific antigen: A prognostic marker of survival in good prognosis metastatic prostate cancer? (EORTC 30892). European Urology 44(2): 182-189.

Davidson, P.J., Hop, W., Kurth, K.H., Fossa, S.D., Waehre, H. $\&$ Schroder, F.H. 1995. Progression in untreated carcinoma of the prostate metastatic to regional lymph nodes (stage T0 to 4, N1 to 3, M0, D1). The Journal of Urology 154(6): 2118-2122.

Denis, L.J., Keuppens, F., Smith, P.H., Whelan, P., de Moura, J.C., Newling, D., Bono, A. \& Sylvester, R. 1998. Maximal androgen blockade: Final analysis of EORTC phase III trial 30853. European Urology 33(2): 144-151.

Egevad, L., Granfors, T., Karlberg, L., Bergh, A. \& Stattin, P. 2002. Prognostic value of the Gleason score in prostate cancer. British Journal of Urology International 89(6): 538-542.

Ezat, S.W.P., Junid, S.M.A.S., Khamis, N., Ahmed, Z., Sulong, S., Nur, A.M., Aizuddin, A.N., Ismail, F., Abdullah, N., Zainuddin, Z.M. \& Kassim, A.Y.M. 2013. Skeletal-related events among breast and prostate cancer patients: Towards new treatment initiation in Malaysia's hospital setting. Asian Pacific Journal of Cancer Prevention 14(5): 3357-3362.

Ferlay, J., Soerjomataram, I., Ervik, M., Dikshit, R., Eser, S.,
Mathers, C., Rebelo, M., Parkin, D.M., Forman, D. \& Bray, F. 2012. GLOBOCAN 2012: Estimated cancer incidence, mortality and prevalence worldwide in 2012. International Journal Cancer 136: E359-E386.

Fosså, S.D., Fredrik, W., Olbjørn, K., Anders, A., Arne, S., Jan-Erik, D., Morten, H., Anders, W. \& The Scandinavian Prostate Cancer Group-7 Investigators 2016. Ten-and 15 -yr prostate cancer-specific mortality in patients with nonmetastatic locally advanced or aggressive intermediate prostate cancer, randomized to lifelong endocrine treatment alone or combined with radiotherapy: Final results of the Scandinavian Prostate Cancer Group-7. European Urology 70(4): 684-691.

Glass, T.R., Tangen, C.M., Crawford, E.D. \& Thompson, I.A.N. 2003. Metastatic carcinoma of the prostate: Identifying prognostic groups using recursive partitioning. The Journal of Urology 169(1): 164-169.

Grönberg, H., Damber, L., Jonson, H. \& Damber, J.E. 1997. Prostate cancer mortality in northern Sweden, with special reference to tumor grade and patient age. Urology 49(3): 374-378.

He, J. \& Chen, W. 2012. Chinese Cancer Registry Annual Report 2012. Beijing: China Military Medical Science Press.

Hittelman, A.B., Purohit, R.S. \& Kane, C.J. 2004. Update of staging and risk assessment for prostate cancer patients. Current Opinion in Urology 14(3): 163-170.

Hong, G.E., Kong, C.H., Singam, P., Cheok, L.B., Zainuddin, Z.M. \& Azrif, M. 2010. Seven-year review of prostate carcinomas diagnosed by TRUS biopsy in a single Malaysian institution. Asian Pacific Journal of Cancer Prevention 11(5): 1351-1353.

Johansson, J.E., Andrén, O., Andersson, S.O., Dickman, P.W., Holmberg, L., Magnuson, A. \& Adami, H.O. 2004. Natural history of early, localized prostate cancer. JAMA 291(22): 2713-2719.

Kishan, A.U., Shaikh, T., Wang, P.C., Reiter, R.E., Said, J., Raghavan, G., Nickols, N.G., Aronson, W.J., Sadeghi, A., Kamrava, M. \& Demanes, D.J. 2017. Clinical outcomes for patients with Gleason score 9-10 prostate adenocarcinoma treated with radiotherapy or radical prostatectomy: A multiinstitutional comparative analysis. European Urology 71(5): 766-773.

Lim, G.C.C. 2002. Overview of cancer in Malaysia. Japanese Journal of Clinical Oncology 32(1): 37-42.

Malaysia National Cancer Registry 2007.

Nesbit, R.M. 1946. Prostatic carcinoma: A follow-up on 795 patients treated prior to the endocrine era and a comparison of survival rates between these and patients treated by endocrine therapy. Surgery 20: 263-272.

Phanphaisarn, A., Patumanond, J., Settakorn, J., Chaiyawat, P. \& Klangjorhor, J. 2016. Prevalence and survival patterns of patients with bone metastasis from common cancers in Thailand. Asian Pacific Journal of Cancer Prevention 17(9): 4335-4340.

Ramsey, S.D., Zeliadt, S.B., Hall, I.J., Ekwueme, D.U. \& Penson, 
D.F. 2007. On the importance of race, socioeconomic status and comorbidity when evaluating quality of life in men with prostate cancer. The Journal of Urology 177(6): 19921999.

Robinson, D. 2008. Prediction of survival in prostate cancer aspects on localized, locally advanced and metastatic disease. Ph.D. Thesis. Linkoping University (Unpublished).

Sandblom, G., Dufmats, M. \& Varenhorst, E. 2000. Long-term survival in a Swedish population-based cohort of men with prostate cancer. Urology 56(3): 442-447.

Satoh, T., Ledesma, D. \& Yoshihara, N. 2018. The economic burden of metastatic castration resistant prostate cancer and skeletal related events in Japanese University Hospitals. Asian Pacific Journal of Cancer Prevention 19(1): 21.

Subahir, M.N., Shah, S.A. \& Zainuddin, Z.M. 2009. Risk factors for prostate cancer in Universiti Kebangsaan Malaysia Medical Centre: A case-control study. Asian Pacific Journal of Cancer Prevention 10(6): 1015-1020.

Sun, L., Caire, A.A., Robertson, C.N., George, D.J., Polascik, T.J., Maloney, K.E., Walther, P.J., Stackhouse, D.A., Lack, B.D., Albala, D.M. \& Moul, J.W. 2009. Men older than 70 years have higher risk prostate cancer and poorer survival in the early and late prostate specific antigen eras. The Journal of Urology 182(5): 2242-2249.

Wallis, C.J., Mahar, A.L., Choo, R., Herschorn, S., Kodama, R.T., Shah, P.S., Danjoux, C., Narod, S.A. \& Nam, R.K. 2016. Second malignancies after radiotherapy for prostate cancer: Systematic review and meta-analysis. British Medical Journal 352(8047): 1-11.

Wilt, T.J. 2012. The prostate cancer intervention versus observation trial: VA/NCI/AHRQ cooperative studies program\# 407 (PIVOT): Design and baseline results of a randomized controlled trial comparing radical prostatectomy with watchful waiting for men with clinically localized prostate cancer. Journal of the National Cancer Institute Monographs 2012(45): 184-190.

Wilt, T.J., Brawer, M.K., Jones, K.M., Barry, M.J., Aronson, W.J., Fox, S., Gingrich, J.R., Wei, J.T., Gilhooly, P., Grob, B.M. \& Nsouli, I. 2012. Radical prostatectomy versus observation for localized prostate cancer. New England Journal of Medicine 367: 203-213.

World Health Organization on Cancer report 2014

Wright, J.L., Salinas, C.A., Lin, D.W., Kolb, S., Koopmeiners, J., Feng, Z. \& Stanford, J.L. 2009. Differences in prostate cancer outcomes between cases with Gleason $4+3$ and Gleason $3+4$ tumors in a population-based cohort. The Journal of Urology 182(6): 2702-2707.

Zagars, G.K., Sands, M.E., Pollack, A. \& von-Eschenbach, A.C. 1994. Early androgen ablation for stage D1 (N1 to N3, M0) prostate cancer: prognostic variables and outcome. The Journal of Urology 151(5): 1330-1333.

Zahir, S.T., Nazemian, M.R., Zand, S. \& Zare, S. 2014. Survival of patients with prostate cancer in Yazd, Iran. Asian Pacific Journal of Cancer Prevention 15(2): 883-886.

Department of Community Health

Hospital Canselor Tuanku Muhriz UKM-Medical Centre

Jalan Yaacob Latif

56000 Cheras, Kuala Lumpur, Federal Territory

Malaysia

*Corresponding author; email: drsham@ppukm.ukm.edu.my

Received: 17 July 2019

Accepted: 28 September 2020 